\title{
Are Unconventional Monetary Policy and Large Scale Fiscal Policy Effective?: The Case of Japan
}

\author{
Yutaka Kurihara \\ Correspondence: Yutaka Kurihara, Professor of International Economics and Finance, Faculty of Economics, Aichi \\ University, 4-60-6 Hiraike Nakamura Nagoya Aichi, 453-8777, Japan.
}

Received: February 27, 2017

Accepted: April 24, 2017

Available online: May 8, 2017

doi:10.11114/afa.v3i2.2410

URL: https://doi.org/10.11114/afa.v3i2.2410

\begin{abstract}
Japan has been under recession for more than twenty years. During that period, drastic measures to overcome deflation have been undertaken. Unconventional monetary policy and huge amounts of fiscal policy have been repeatedly implemented. This paper examines whether or not these policies were effective with a focus on exchange rates. The empirical results showed that recent monetary policies are effective at present and the effectiveness of fiscal policies has been decreasing. On the other hand, exchange rate depreciation has boosted the Japanese economy. Stock prices and wages are related strongly with the economic boom. These variables are important factors to the economy.
\end{abstract}

Keywords: exchange rate, fiscal policy, monetary policy, real GDP

\section{Introduction}

\subsection{General View}

In Japan, deflation has been ongoing, so the Japanese central bank, Bank of Japan (BOJ), and the government began to take drastic measures to overcome inflation. The unconventional monetary policy, which is explained later, was the first policy enacted by the BOJ among central banks all over the world. Also, the Japanese ratio of debt to GDP is already highest among all of the developed countries. On the other hand, there is some concern not only from academic fields but also from business fields about these drastic measures.

This paper examines whether or not these policies were effective in promoting the economy with a focus on exchange rate movements for analyses. Exchange rates are not and cannot be policy variables; however, it would be natural that most policymakers are very concerned and interested in exchange rates movements, as these have lately affected their economies strongly. It is an unwritten law for policymakers in many countries to avoid manipulation of exchange rates. However, exchange rate changes are said to affect almost every macroeconomic variable such as exports, imports, trade balance, consumption, investment, wages, interest rates, and so on. The link between the exchange rate and each macro variable has its own literature, and domestic output-exchange rate nexus is no exception.

Some studies have not considered exchange rates when examining the recent Japanese economy. Kurihara (2010) examined the effectiveness of BOJ intraday financial policies. Ueda (2011) examined the monetary policy adopted by the Bank of Japan 1998-2006. Fukuda (2011) showed that zero interest rate policy by the BOJ caused the short-term interest rate to decline to zero and was somewhat effective at reducing the spreading in the call (interbank) markets. Hanabusa (2010) showed that the zero interest rate policy stabilized the long-term interest rates in Japan. Kurihara (2012) used daily data to examine the impact of BOJ news announcements on interest rates in Japan. Honda, Kuroki, and Tachibana (2013) and Kurihara (2013) examined recent Japanese monetary policy including asset prices using VARs. Schenkelberg and Watzka (2013) showed that Japanese quantitative easing policy shock leads to a significant decrease in long-term interest rates and stimulates the output and the price level; however, the effects were short-lived. Takahashi (2013) showed that although no clear conclusion can be obtained about the effectiveness in terms of boosting business activities, the zero interest rate policy and quantitative easing policy had clear effects in terms of stabilizing the financial system in Japan. Recently, for example, Kimura and Nakajima (2016) showed that increased bank reserves lowers long-term interest rates during unconventional policy periods and that the impulse responses of inflation and the output gap to a bank reserve shock are positive but uncertain. Michelis and Iacoviello (2016) showed that Japan has made some progress toward overcoming deflation; however, further measures are needed to raise inflation $2 \%$ in a stable condition. However, few studies have examined the recent Japanese economy. 
How can exchange rates influence economies? When domestic income is shifted from workers to producers, consumption could decline causing domestic recession, hence contractionary devaluation, to occur. This result is one aspect of the impact of exchange rates. However, if devaluation results in an increase in net exports, it could offset the decline in consumption by expanding depreciation in the economy. This uncertainty about the effects of exchange rate depreciation on the domestic economy becomes uncertain if one incorporates the supply side effects with the increase of the cost of imported goods; increased costs would decline the supply. If the decline in the supply offsets expansion in the demand, currency depreciation becomes contractionary (Bahmani-Oskooee \& Mohammadian, 2016). Currency depreciation has been said to have positive or negative effects on domestic economy, and most previous studies that have tried to examine this issue have been inconclusive.

Kappler, Reisen, Schularick, and Turkisch (2013) showed that exchange rate appreciation has strong effects on the current account. Yang, Zhang, and Tokgoz (2013) found that Chinese currency appreciation had positive impact on the GDP of major countries. Ziaei (2014) showed that interest rates in Gulf Corporation Council (GCC) countries change positively in response to unpredictable increases in monetary base. Kohler, Manalo, and Perera (2014) found that a temporary $10 \%$ depreciation fosters real GDP in Australia by $0.25-0.50 \%$ over $1-2$ years. Manalo, Perera, and Rees (2015) found that a temporary $10 \%$ appreciation lowers the level of real GDP over $1-2$ years by $0.3 \%$. On the other hand, Kalyoncu, Artan, Tezekici, and Ozturk (2008) found the relationship of cointegration between the real exchange rate and the real output. Some studies have examined the relationship between exchange rates and the macro economy for the case of Japan. Claus, Claus, and Krippner (2016) showed a small response in exchange rates existed during the first period of the unconventional monetary policy era in Japan and a significant response since 2006. Fukuda and Doita (2016) showed that that a small change in the exchange rate has no effect on exports because of the fixed costs related to a shift in the business factory location to other countries. This finding also implies that a change in the exchange rate has a significant effect on exports either when exchange rate depreciation causes strong external demand or when appreciation causes weak external demand. Few studies have treated exchange rates clearly.

\subsection{Monetary Policy}

The BOJ conducts monetary policy with the goal of maintaining price stability, which is thought to be the first priority because it is considered to be the foundation of economic activity. This goal, price stability, has been employed by many countries' central banks, and Japan (BOJ) is no exception. On the other hand, deflation rather than inflation has damaged the Japanese economy. Overcoming deflation is the main task for policymakers. In 2001, the BOJ raised the outstanding balance of the current account at the BOJ. This objective can be perceived as a change from holding a level of reserves at the BOJ to one that transfers funds into lending capital to foster the economy and remove deflation. Traditional monetary policies, based on interest rates, were impossible because interest rates are almost zero at that time. Under this unconventional quantitative easing policy, the BOJ purchased huge amounts of Japanese government bonds to reach its target of current account balances held by financial institutions such as banks. With interest rates at the lower bound of $0 \%$, the BOJ set a new and drastic goal to purchase government bonds from financial institutions and to raise the level of cash reserves held by private financial institutions such as banks. This was called unconventional monetary policy, which was unprecedented in the world at that time. However, only a few studies have examined this policy despite that such examination are very important. One serious reason for the lack of studies is that only a short time has passed since this unprecedented monetary policy was conducted.

On April 4, 2013, the policy board of the BOJ decided to implement quantitative and qualitative monetary easing policy, which a more aggressive monetary policy. The BOJ decided to achieve the price target of $2 \%$ in terms of the year-to-year rate of change in consumer prices. Some researchers said that the BOJ introduced a new phase of monetary easing both in terms of quantity and quality. The BOJ decided to double the monetary base and the amounts outstanding of Japanese government bonds at the bank as well as exchange-traded funds (ETFs) in two years and more than doubled the maturity of Japanese government bond purchases (quality). The BOJ started to hold risky assets instead of safe assets to foster the economy. These moves should not be considered as manipulating or keeping stock prices.

McCallum (1994) investigated properties of a policy rule that specifies the use of the monetary base as a monetary policy that is designed to keep the nominal GDP growing smoothly at a noninflationary rate instead of prices. This article has been cited often. Razzak (2003) employed McCallum's rule for some countries. Judd and Motley (1993) presented a feedback rule in which central banks change the interest rate in response to divergence between actual and targeted nominal GDP growth rate. Dueker and Fischer (1998) provided potential effectiveness of the indicator model as a policy indicator for the monetary base in Switzerland. Many studies have included other rules for monetary policy in theoretical models or for empirical analysis (see, e.g., Ida, 2013). On the other hand, a price-level target model was advocated by Clark (1988), among others. Recently, the nominal GDP-targeting or inflation-targeting rule has been discussed, and more than 20 countries have introduced inflation targeting. The Taylor rule was presented and many articles, including those that employed modified rules, have been presented for this rule. Anyway, one can guess that 
GDP or real GDP should be considered first when examining the effects of economic policies.

\subsection{Fiscal Policy}

Until recently, fiscal expansion along with the huge debt have contributed to damaging the economy. For example, debt and deficit discipline have been considered to endure in many countries, such as euro-introducing countries. It is interesting to note that some papers recently have indicated that fiscal expansion under debt has less serious issues; instead other studies have recommend aggressive fiscal expansion. Hansen and Imrohoroglu (2016) showed that high taxes highlight the importance of considering alternatives that attenuate the projected increases in public spending and/or enlarge the tax basement. Also, some studies have examined Japanese fiscal policy. Afonso and Jalles (2014) indicated that long-run fiscal sustainability cannot be rejected. Yoshino and Vollmer (2014) showed that government debt obligations in Japan are held by Japanese residents and monetary policy is autonomous, so Japan has not yet suffered from a serious government debt problem. Japanese residents are willing to absorb increasing amounts of Japanese government debts (especially, national bonds) without high interest rates. This specific issue in Japan differs from that in other countries, particularly those that are not willing to be risk-takers. Instead, they are willing to hold only safe assets despite that the interest rates are almost zero. Sakuragawa and Sakuragawa (2016) showed that when there is a domestic bias in the asset portfolio of domestic residents' bondholders, these investors appear not to have access to any assets that hedge fiscal risk.

On the other hand, if Japan's sovereign debt expands, fiscal crisis may occur in the future. Some people fear that such an issue may occur at a breaking point that cannot be predicted by most market participants. Arai and Nakazawa (2014) indicated that a large primary surplus, $13.8-18.7 \%$ of GDP, is necessary not to prevent the debt:GDP ratio from expanding automatically. Kameda (2014a) showed that the real budget deficit in 2008 brings an approximate 2-3\% increase in the Japanese government bond yields, which declined the real GDP by $0.39-0.63 \%$ in 2008 . Kameda (2014b) found that when the fiscal condition of the government is bad, the aggregate demand effects for expenditures are weak. Ueda, Yoneta, and Ota (2014) showed that current fiscal policies in Japan are distracted from satisfying intertemporal budget constraints and achieving good intertemporal resource allocation. Ko and Morita (2015) found that that about 2\% growth or a Ricardian fiscal stance can keep the debt-to-GDP ratio in attainable condition. Miyazaka and Yamada (2015) showed that relative to the achievement the government target of fiscal consolidation by 2020, the Japanese government's condition is serious. Velinov (2015) indicated that Finland, Norway, Sweden, Switzerland, and the United Kingdom have sustainable fiscal policies; Greece and Japan do not.

Ko and Morita (2015) found that fiscal policy caused more effective consumption in era of high rule-of-thumb households. Miyazaki (2016) showed that a tax reduction and subsidy to foster the adoption of ecofriendly cars in Japan increased automobile production; however, a fiscal program to promote the purchase of energy-efficient household appliances had no influence on appliance production in Japan. However, Hayashi (2014) showed that government policies have failed to stimulate Japan's GDP to the expected level even with the promotion of Abenomics (Abe is the name of the Japanese prime minister).

There are some necessary links between monetary and fiscal policies. Kurihara (2014) indicated that Abenomics showed some influence on increasing stock prices. Fukuda (2011) showed that, under Abenomics, foreign investors were eager to buy Japanese stocks and sell the Japanese yen, although domestic investors were not eager. Lam (2015) showed that, although the BOJ has successfully depreciated the yen by about $30 \%$ and maintained a low interest rate environment, plenty of challenges lie ahead. Kurihara (2016) found that a zero interest rate in Japan and the exchange rate of yen/US dollar influenced Japanese stock prices positively. On the other hand, Fujiwara, Nakazono, and Ueda (2015) showed that Japan seemed to have moved closer to a long-term liquidity trap; no clear difference has been found before and after the introduction of Abenomics. Only a short time has passed since the drastic measures such as Abenomics were employed, so there is no consensus on the evaluation of economic policies.

It can be safely said that household saving habits in Japan help the absorption of government bonds. This is the most important reason that the Japanese government may have huge debt in addition to some room to raise the tax rate. Very huge debt seems to have had no influence on the decline of the Japanese economy. However, market participants and national residents have known that Japanese debt is very heavy. So, there seems some possibility that people, including the Japanese, surely know that the debt is heavy; that knowledge may incur unstable growth or recession. There seems some possibility that they might start to act suddenly. It should not be forgotten that the Japanese economy faces an aging population and increasing social welfare expenses. Moreover, foreign investors may escape from investing in Japanese financial markets when market conditions worsen. Their actions would be swifter than those of Japanese investors.

This paper investigates whether economic policies have succeeded in overcoming recession while considering the effect of exchange rate movements on economic performance (i.e., GDP) in Japan. Section 2 provides theoretical aspects of this paper. Following section 2, empirical analyses are shown in section 3. Finally, a brief summary is provided in the conclusion. 


\section{Method}

This paper, based on the empirical study of Bahmani-Oskooee and Mohammadian (2016), employs a model that includes a measure of monetary policy (i.e., fiscal policy in addition to real exchange rate). The empirical analyses are conducted, and this equation is estimated empirically to examine the recent effects of monetary and fiscal policies conducted in Japan to overcome deflation. In contrast to some existing studies, the exchange rate is added for estimation because of its recent importance in affecting the economy.

$$
\ln Y t=\alpha 1+\alpha 2 \ln M t+\alpha 3 \ln G t+\alpha 4 \ln R E X t+\varepsilon t
$$

where $\mathrm{Y}$ is the real GDP in Japan, M is the real M2 measure of money supply, G is real government spending, and REX is the real effective exchange rate (against the U.S. dollar). If monetary and fiscal policies are to be expansionary, estimates of $\alpha 3$ and $\alpha 4 c$ are expected to be positive. As a decline of the real effective exchange rate signifies depreciation, a negative estimate of $d$ will be an indication of depreciation of Japanese currency, the yen, and a positive estimate of $\alpha 4$ will be an indication of contractionary depreciation. Other variables, stock prices, and wages were included regardless of influence on the growth.

\section{Results}

Equation (1) is estimated for the case of Japan. Quarterly data were used for estimation, and the sample period is from 1990Q1 to 2016Q2. Recent data from 2001, when drastic monetary expansion started, to present, are also examined. Economic policies and exchange rates, stock prices, and wages were added for estimation whether or not economic policies were effective. Stock market data were NIKKEI225 (average), the Japanese representative stock market indicator. All of the data are rates to avoid unit roots, and original data are from IFS (IMF).

The results are shown in Tables 1 and 2.

Table 1. Full period (1990Q1-2016Q2): Dependent variable, real GDP

\begin{tabular}{llllll}
\hline $\mathrm{C}$ & $1.57 \mathrm{E}+13$ & $2.62 \mathrm{E}+13 *$ & $3.65 \mathrm{E}+13 * *$ & $4.67 \mathrm{E}+13 * * *$ & $5.72 \mathrm{E}+13 * * *$ \\
& $(1.134)$ & $(1.835)$ & $(2.492)$ & $(3.112)$ & $(3.733)$ \\
M2 & -0.035 & -0.010 & 0.013 & 0.044 & 0.077 \\
& $(-0.631)$ & $(-0.179)$ & $(0.225)$ & $(0.696)$ & $(1.168)$ \\
Government expenditure & $4.028 * * *$ & $3.722^{* * *}$ & $3.423 * * *$ & $3.067 * * *$ & $2.688^{* * *}$ \\
& $(7.891)$ & $(6.948)$ & $(6.155)$ & $(5.322)$ & $(4.498)$ \\
Real exchange rate & $1.59 \mathrm{E}+12^{* * * *}$ & $1.60 \mathrm{E}+12^{* * *}$ & $1.60 \mathrm{E}+12^{* * *}$ & $1.61 \mathrm{E}+12 * * *$ & $1.62 \mathrm{E}+12 * * *$ \\
& $(11.399)$ & $(11.041)$ & $(10.779)$ & $(10.612)$ & $(10.457)$ \\
Adj.R2 & 0.923 & 0.915 & 0.908 & 0.900 & 0.892 \\
F-statistic & 604.512 & 538.551 & 487.667 & 443.482 & 404.028 \\
Prob (F-statistic) & 0.000 & 0.000 & 0.000 & 0.000 & 0.000 \\
Durbin-Watson & 0.128 & 0.141 & 0.122 & 0.111 & 0.127 \\
\hline Time lag & 0 & 1 & 2 & 3 & 4 \\
\hline
\end{tabular}

Note) $* * *$ denotes significant at $1 \%, * *$ at $5 \%$, and $*$ at $10 \%$

Table 2. Recent period (2001Q1-2016Q2): Dependent variable, real GDP

\begin{tabular}{|c|c|c|c|c|c|}
\hline $\mathrm{C}$ & $\begin{array}{l}1.29 \mathrm{E}+14 \\
(1.426)\end{array}$ & $\begin{array}{l}1.46 \mathrm{E}+14 \\
(1.686)\end{array}$ & $\begin{array}{l}4.00 \mathrm{E}+13 \\
(0.406)\end{array}$ & $\begin{array}{l}1.25 \mathrm{E}+14 \\
(1.076)\end{array}$ & $\begin{array}{l}-2.39 \mathrm{E}+14 * * * \\
(-17.824)\end{array}$ \\
\hline M2 & $\begin{array}{l}0.276 * * * \\
(3.374)\end{array}$ & $\begin{array}{l}0.315 * * * \\
(3.874)\end{array}$ & $\begin{array}{l}0.224 * * \\
(2.546)\end{array}$ & $\begin{array}{l}0.289 * * \\
(2.914)\end{array}$ & $\begin{array}{l}0.174 * * * \\
(6.156)\end{array}$ \\
\hline $\begin{array}{l}\text { Government } \\
\text { expenditure }\end{array}$ & $\begin{array}{l}1.204 \\
(0.767)\end{array}$ & $\begin{array}{l}0.736 \\
(0.484)\end{array}$ & $\begin{array}{l}2.633 \\
(1.571)\end{array}$ & $\begin{array}{l}1.309 \\
(0.687)\end{array}$ & $\begin{array}{l}-1.999 * * * \\
(-4.889)\end{array}$ \\
\hline Real exchange rate & $\begin{array}{l}2.10 \mathrm{E}+11 * * \\
(2.299)\end{array}$ & $\begin{array}{l}2.01 \mathrm{E}+11 * * \\
(2.389)\end{array}$ & $\begin{array}{l}1.67 \mathrm{E}+11 * \\
(1.818)\end{array}$ & $\begin{array}{l}8.62 \mathrm{E}+10 \\
(0.765)\end{array}$ & $\begin{array}{l}-5.30 \mathrm{E}+10 * * \\
(1.989)\end{array}$ \\
\hline Stock & & & & & $\begin{array}{l}4.55 \mathrm{E}+10 * * \\
(1.989)\end{array}$ \\
\hline Wage & & & & & $\begin{array}{l}7.95 \mathrm{E}+12 * * * \\
(20.733)\end{array}$ \\
\hline Adj.R2 & 0.945 & 0.957 & 0.940 & 0.922 & 0.989 \\
\hline F-statistic & 117.464 & 127.688 & 106.975 & 79.870 & 2740.336 \\
\hline Prob (F-statistic) & 0.000 & 0.000 & 0.000 & 0.000 & 0.000 \\
\hline Durbin-Watson & 1.132 & 1.322 & 1.376 & 1.146 & 0.502 \\
\hline Time lag & 0 & 1 & 2 & 3 & 0 \\
\hline
\end{tabular}

Note) $* * *$ denotes significant at $1 \%, * *$ at $5 \%$, and $*$ at $10 \%$

The results are quite interesting. Monetary policy was effective during the recent period; however, it was not so effective in the past. On the other hand, the results of fiscal policies produced opposite results. Fiscal policies were effective in the past; however, they have not been so effective recently. Recent experiences have suggested that monetary policies are effective; however, fiscal policies are not so effective. 
Monetary policies seems effective, at least at present, and the effect of fiscal policies has been decreasing. For the fiscal policies, the Japanese government was able to expand as Japanese deficit was not very large. However, a huge amount of fiscal deficit has accumulated, so it is difficult to expand easily. Also, one should note that the average age of the Japanese population is increasing, so there is some possibility that fiscal expansion becomes gradually less and less effective. Citizen may not wish to consume a lot when fiscal policy is changed. The same thing can be adapted for monetary policy. The aging population may become a serious problem in the future with decreased effectiveness of policies .

On the other hand, exchange rate deprecation boosted the Japanese economy in the whole period and the recent period. There is some possibility that a small change in the exchange rate has no effect on exports because of the fixed costs associated with shifting the plant location to other countries as explained before; however, the results show that a change in the exchange rate has a significant effect on exports either when depreciation coincides with strong external demand or when appreciation coincides with weak external demand.

Finally, stock prices and wages are related strongly to economic stimuli. It is difficult to predict the results and it is not good policy to manipulate these variables; however, they are important factors in economic growth.

\section{Conclusions}

In Japan, drastic economic policies (i.e., monetary and fiscal policies) were conducted beginning in the 2000s. This paper found that monetary policies are effective, at least at present, and the effect of fiscal policies has been decreasing. For fiscal policies, the Japanese government has been able to expand as the Japanese deficit was not very large. However, a huge amount of fiscal deficit has accumulated, so it is difficult to expand easily. Also, one should note that the average age of the Japanese population is increasing, so there is some possibility that fiscal expansion may become less and less effective. Under these circumstances, citizens may prefer not to consume a lot. Also, it cannot be concluded that monetary policies in the past were unnecessary. Without them, the Japanese economy would deteriorate.

It should be noted that exchange rate depreciation boosts the economy. A change in the exchange rate has an influence on the economy. Exchange rates are not and cannot be policy measures in the world, including Japan; however, the effect on the economy is surely positive. Depreciation of the yen is strongly related to boosts in the economy, although one must be aware of side effects.

Aoyagi, Ganelli, and Murayama (2016) showed that full implementation of structural reforms-especially labor market reforms - is necessary both to boost the economy and to increase equality. Too much reliance on the policies is dangerous; however, policies that are basic and understandable to everyone are needed to overcome deflation and recession. Some economists say that structural reform is important for the Japanese economy. To boost the economy, it should be emphasized much more than before. Structural reform is and will be surely important and further study on this issue is necessary.

\section{Acknowledgements}

I appreciate valuable comments and suggestions of reviewers. This paper is supported by JSPS KAKENHI Grant Number $15 \mathrm{H} 03366$.

\section{References}

Afonso, A., \& Jalles, J. T. (2014). A longer-run perspective on fiscal sustainability. Empirica, 41(4), 821-847. https://doi.org/10.1007/s10663-013-9240-0

Aoyagi, C., Ganelli, G., \& Murayama, K. (2016). How inclusive Abenomics. Journal of International Commerce, Economics, and Policy, 7(1), 1-28. https://doi.org/10.1142/S1793993316500058

Arai, R., \& Nakazawa, M. (2014). A numerical analysis of Japan's fiscal sustainability in a simple OLG model. Applied Economics Letters, 21(17), 1194-1197. https://doi.org/10.1080/13504851.2014.916382

Bahmani-Oskooee, M., \& Mohammadian, A. (2016). Asymmetry effects of exchange rate changes on domestic production: evidence from nonlinear ARDL approach. Australian Economic Papers, 55(3), 181-191. https://doi.org/10.1111/1467-8454.12073

Clark, P. K. (1988). Postwar developments in business cycle theory-a moderately classical perspective: comment. Journal of Money, Credit, and Banking, 20(3), 476-478. https://doi.org/10.2307/1992525

Claus, E., Claus, I., \& Krippner, L. (2016). Monetary policy spillovers across the Pacific when interest rates are at the zero lower bound. Asian Economic Papers, 15(3), 1-27. https://doi.org/10.1162/ASEP_a_00448

Dueker, M. J., \& Fischer, A. M. (1998). A guide to nominal feedback rules and their use for monetary policy. Federal Reserve Bank of St. Louis, 80(4), 55-63. 
Fujiwara, I., Nakazono, Y., \& Ueda, Y. (2015). Policy regime change against chronic deflation? Policy option under a long-term liquidity trap. Journal of the Japanese and International Economies, 37, 59-81. https://doi.org/10.1016/j.jjie.2015.05.005

Fukuda, S. (2011). Market-specific and currency-specific risk during the global financial crisis: Evidence from the interbank markets in Tokyo and London. Journal of Banking \& Finance, 36(12), 3185-3196. https://doi.org/10.1016/j.jbankfin.2012.01.003

Fukuda, S., \& Doita, T. (2016). Unconventional monetary policy and its external effects: Evidence from Japan's exports. Developing Economies, 54(1), 59-79. https://doi.org/10.1111/deve.12094

Hanabusa, K. (2010). The effects of zero interest rate commitment in Japan. Applied Economics Letters, 17(13), 1273-1277. https://doi.org/10.1080/00036840902881835

Hansen, G. D., \& Imrohoroglu, S. (2016). Fiscal reform and government debt in Japan: A neoclassical perspective. Review of Economic Dynamics, 21, 201-24. https://doi.org/10.1016/j.red.2015.04.001

Hayashi, T. (2014). Is it abenomics or post-disaster recovery? A counterfactual analysis. International Advances in Economic Research, 20(1), 23-31. https://doi.org/10.1007/s11294-013-9450-z

Honda, Y., Kuroki, Y., \& Tachibana, M. (2013). An injection of base money at zero interest rates: Empirical evidence from the Japanese experience 2001-2006. Japanese Journal of Monetary and Financial Economics, 1(1), 1-24.

Ida, D. (2013). Optimal monetary policy rules in a two-country economy with a zero bound on nominal interest rate. The North American Journal of Economics and Finance, 24, 223-242. https://doi.org/10.1016/j.najef.2012.10.006

Judd, J. P., \& Motley, B. (1993). Using nominal GDP rule to guide discretionary monetary policy. Reserve Bank of San Francisco Economic Review, 1993(3), 3-11.

Kalyoncu, H., Artan, S., Tezekici, S., \& Ozturk, I. (2008). Currency devaluation and output growth: An empirical evidence from OECD countries. International Research Journal of Finance and Economics, 14, 232-238.

Kameda, K. (2014a). Budget deficits, government debt, and long-term interest rates in Japan. Journal of the Japanese and International Economies, 32, 105-124. https://doi.org/10.1016/j.jjie.2014.02.001

Kameda, K. (2014b). What causes changes in the effects of fiscal policy? A case study of Japan. Japan and the World Economy, 31, 14-31. https://doi.org/10.1016/j.japwor.2014.04.003

Kappler, M., Reisen, H., Schularick, M., \& Turkisch, E. (2013). The macroeconomic effects of large exchange rate appreciations. Open Economics Review, 24(3), 471-494. https://doi.org/10.1007/s11079-012-9246-4

Kimura, T., \& Nakajima, J. (2016). Identifying conventional and unconventional monetary policy shocks: a latent threshold approach. Journal of Macroeconomics, 16(1), 277-300. https://doi.org/10.1007/s11079-012-9246-4

Ko, J. H., \& Morita, H. (2015). Fiscal sustainability and regime shifts in Japan. Economic Modelling, 46, 364-375. https://doi.org/10.1016/j.econmod.2015.02.008

Kohler, M., Manalo, J., \& Perera, D. (2014). Exchange rate movements and economic activity. RBA Bulletin, March, 47-54.

Kurihara, Y. (2010). Has inflation targeting been effective? International Journal of Business, 15(4), 411-424.

Kurihara, Y. (2012). The impact of the Bank of Japan's news announcements on the Japanese yen, U.S. dollar, and the euro. Journal of Applied Finance and Banking, 2(3), 39-50.

Kurihara, Y. (2013). The effectiveness of financial policy in the Japanese financial markets. International Journal of Economy, Management, and Social Science, 2(5), 161-165.

Kurihara, Y. (2014). Has interest rate policy of the Bank of Japan influenced financial markets? Journal of Finance \& Economics, 2(2), 77-85. https://doi.org/10.12735/jfe.v2i2p77

Kurihara, Y. (2016). Effectiveness of the zero interest rate policy for financial markets in Japan: principal components analysis. Applied Economics and Finance, 3(3), 103-111. https://doi.org/10.11114/aef.v3i3.1532

Lam, K. C. (2015). Did Abenomics' two arrows hit the bulls? Journal of Applied Finance and Banking, 5(3), 47-61.

Manalo, J., Perera, D., \& Rees, D. M. (2015). Exchange rate movements and the Australian economy. Economic Modelling, 47, 53-62. https://doi.org/10.1016/j.econmod.2015.02.013

McCallum, B. (1994). Monetary Policy Rules and Financial Stability. NBER Working Paper, W4692. https://doi.org/10.3386/w4692

Michelis, A., \& Iacoviello, M. (2016). Raising an inflation target: The Japanese experience with abenomics. European 
Economic Review, 88, 67-87. https://doi.org/10.1016/j.euroecorev.2016.02.021

Miyazaka, K., \& Yamada, J. (2015). The growth strategy of abenomics and fiscal consolidation. Journal of the Japanese and International Economies, 37, 82-99. https://doi.org/10.1016/j.jjie.2015.05.004

Razzak, W. A. (2003). Is the Taylor rule really different from the McCallum rule? Contemporary Economic Policy, 21(4), 445-457. https://doi.org/10.1093/cep/byg024

Sakuragawa, M., \& Sakuragawa, Y. (2016). Absence of safe assets and fiscal crisis. Journal of the Japanese and International Economies, 40, 59-76. https://doi.org/10.1016/j.jjie.2016.03.006

Schenkelberg, H., \& Watzka, S. (2013). Real effects of quantitative easing at the zero lower bound: structural VAR based evidence from Japan. Journal of International Money and Finance, 33, 327-357. https://doi.org/10.1016/j.jimonfin.2012.11.020

Takahashi, W. (2013). Japanese monetary policy: Experience from the lost decades. International Journal of Business, 18(4), 287-306.

Ueda, K. (2011). Japan's bubble, the USA's bubble and China' bubble. China and World Economy, 19(1), 47-62. https://doi.org/10.1111/j.1749-124X.2011.01226.x

Velinov, A. (2015). Assessing fiscal-policy sustainability: on the different States of the debt-to-GDP process. Finan Archiv, 71(4), 415-439. https://doi.org/10.1628/001522115x14385891669733

Yang, J., Zhang, W., \& Tokgoz, S. (2013). Macroeconomic impacts of Chinese currency appreciation on China and the rest of world: A global CGE analysis. Journal of Policy Modeling, 35(6), 1029-1042. https://doi.org/10.1016/j.jpolmod.2013.07.003

Yoshino, N., \& Vollmer, U. (2014). The sovereign debt crisis: Why Greece, but not Japan? Asia Europe Journal, 12(3), 325-344. https://doi.org/10.1007/s10308-014-0387-5

Ziaei, S. M. (2014). Evaluating the effects of monetary policy shocks on aggregate demand components in GCC countries: Evidence from SVAR. The Journal of Developing Areas, 48(1), 405-423. https://doi.org/10.1353/jda.2014.0004

\section{Copyrights}

Copyright for this article is retained by the author(s), with first publication rights granted to the journal.

This is an open-access article distributed under the terms and conditions of the Creative Commons Attribution license which permits unrestricted use, distribution, and reproduction in any medium, provided the original work is properly cited. 